\title{
Endocrine modulation of the recipient environment affects development of bovine testis tissue ectopically grafted in mice
}

\author{
Jose R Rodriguez-Sosa ${ }^{1,2}$, Guilherme M J Costa ${ }^{3}$, Rahul Rathi ${ }^{1}$, Luiz R França ${ }^{3}$ and Ina Dobrinski ${ }^{1,2}$ \\ ${ }^{1}$ Center for Animal Transgenesis and Germ Cell Research, New Bolton Center, University of Pennsylvania, Kennett \\ Square, Pennsylvania 19348, USA, ${ }^{2}$ Department of Comparative Biology and Experimental Medicine, Faculty of \\ Veterinary Medicine, University of Calgary, Calgary, Alberta T2N 1N4, Canada and ${ }^{3}$ Department of Morphology, \\ Institute of Biological Sciences, Federal University of Minas Gerais, Belo Horizonte, Minas Gerais 31270-901, Brazil
}

Correspondence should be addressed to I Dobrinski at Department of Comparative Biology and Experimental Medicine, Faculty of Veterinary Medicine, University of Calgary, 3330 Hospital Drive NW, Calgary, Alberta T2N 4N1, Canada; Email: idobrins@ucalgary.ca

\begin{abstract}
Testis tissue xenografting is a powerful approach for the study of testis development and spermatogenesis, and for fertility preservation in immature individuals. In bovine testis xenografts, maturation and spermatogenesis are inefficient when compared to other species. To evaluate if exogenous modulation of the endocrine milieu in recipient mice will affect spermatogenic efficiency in xenografts from newborn calves, recipient mice were treated with the $\mathrm{GnRH}$ antagonist acyline $(5 \mathrm{mg} / \mathrm{kg}$ s.c. every 2 weeks) to reduce testosterone production in xenografts, or with 6-N-propyl-2-thiouracil (PTU, 0.1\% in drinking water for 4 weeks), to induce transient hypothyroidism in recipient mice respectively. Both treatments altered developmental parameters of testis xenografts and reduced germ cell differentiation. While the effects of acyline treatment can be attributed to inhibition of GnRH and gonadotropin action, lower Sertoli cell numbers and decreased seminiferous tubule length observed after PTU treatment were opposite to effects reported previously in rats. Regardless of treatment, Sertoli cells underwent only partial maturation in xenografts as Müllerian inhibiting substance and androgen receptor expression were lower than in donor and adult tissue controls respectively. In conclusion, although treatments did not result in improvement of maturation of bovine testis xenografts, the current study demonstrates that exogenous modulation of the endocrine milieu to affect xenograft development in recipient mice provides an accessible model to study endocrine control of spermatogenesis in large donor species.

Reproduction (2012) 144 37-51
\end{abstract}

\section{Introduction}

Testicular function and postnatal testis development are primarily regulated by the hypothalamic-pituitarygonadal (HPG) axis. Specific hypothalamic cells produce and release $\mathrm{GnRH}$ that stimulates the anterior lobe of the pituitary to produce and release $\mathrm{LH}$ and $\mathrm{FSH}$ to the blood stream. In the testis, LH acts on Leydig cells and FSH on Sertoli cells to trigger a wide variety of cellular responses that support normal steroidogenesis and spermatogenesis. Production of androgens by Leydig cells and inhibin by Sertoli cells induces a negative feedback on the hypothalamus and pituitary to regulate the release of $\mathrm{GnRH}$ and gonadotropins (Senger 2003a, 2003b).

Slow testis development during infancy is due to low gonadotropin support rather than a lack of sensitivity to gonadotropins. Low gonadotropin support, particularly of $\mathrm{LH}$, is related to hypersensitivity of the hypothalamus to sex steroids typical of the infant period (Ojeda \&
Terasawa 2002). If exposed to adult levels of gonadotropins the infant testis is able to initiate and complete pubertal development. When testis tissue from immature large animals is ectopically transplanted into immunodeficient castrated adult mice, the tissue is able to survive and reestablish the HPG axis by initiating hormonal signaling with the hypothalamus and pituitary gland of the rodent host. As a result, testis tissue undergoes full development and produces fertilizationcompetent sperm (Honaramooz et al. 2002, 2008, Schlatt et al. 2002). Testis tissue xenografting has been applied to a wide variety of species and emerged as an attractive alternative for the study of testis development and spermatogenesis, and for fertility preservation in immature individuals (Rodriguez-Sosa \& Dobrinski 2009, Rodriguez-Sosa et al. 2011a).

The thyroid gland plays an important role in regulating testicular function and development. Thyroid hormones have been shown to play a role in testis development in rodents (reviewed by Wagner et al. 2008, 2009) and 
domestic species, such as cattle (Majdic et al. 1998), sheep (Chandrasekhar et al. 1985, Fallah-Rad et al. 2001), and pigs (McCoard et al. 2003). Thyroid hormone receptors are present in both Sertoli cells and Leydig cells (McCoard et al. 2003, Wagner et al. 2008). In the rodent testis, elevated triiodothyronine $\left(T_{3}\right)$ promotes Sertoli cell maturation by inhibiting proliferation and inducing differentiation (van Haaster et al. 1993, Cooke et al. 1994). Moreover, $T_{3}$ modulates Leydig cell steroidogenesis (Maran 2003) and promotes differentiation of mesenchymal precursors into prepubertal and adult Leydig cells (Ariyaratne et al. 2000, Baker et al. 2003). In addition, androgens have a direct influence on thyroid cell proliferation (Rossi et al. 1996, Banu et al. $2002 a, 2002 b$ ). Presence of androgen receptors (ARs) has been reported in thyroid tissue of rat, primate, and human (Sheridan et al. 1984, Miki et al. 1990, Banu et al. 2002a). In dogs, the incidence of hypothyroidism is increased in gonadectomized individuals (Milne \& Hayes 1981). Changes in the histological and ultrastructural characteristics of the thyroid that are induced by castration in males are reversed by androgen supplementation (Dehkordi \& Parchami 2010). Although it is likely that this thyroid-testis interplay is also reestablished after ectopic transplantation of testis tissue in recipient mice, this remains to be demonstrated.

In testis tissue xenografting, manipulation of the endocrine environment of the rodent host is attractive as this opens new avenues for study of endocrine control of testicular maturation and spermatogenesis in large animal donor species (Rathi et al. 2006, 2008). In bovine testis xenografts, efficiency of maturation and spermatogenesis is lower when compared to other species (reviewed by Rodriguez-Sosa \& Dobrinski 2009). While maturation of xenografts of pig and monkey testis is advanced in relation to testis tissue in situ (Honaramooz et al. 2002, 2004), maturation of bovine xenografts is only slightly advanced or similar to in situ controls (Rathi et al. 2005). Moreover, whereas in pig and sheep the number of seminiferous tubules with complete spermatogenesis is $>50 \%$ (Zeng et al. 2006, Arregui et al. 2008, Rodriguez-Sosa et al. 2010), in bovine xenografts this number is usually $<15 \%$ (Oatley et al. 2005, Rathi et al. 2005, Schmidt et al. 2006, Huang et al. 2008). Low efficiency of maturation and spermatogenesis of testis xenografts have also been described in cat (Snedaker et al. 2004, Kim et al. 2007) and horse (Rathi et al. 2006). In bovine testis xenografts, this was associated with meiotic arrest (Rathi et al. 2005), but the causes and mechanisms behind this are still unclear.

While development of hamster testis tissue grafted in mice is primarily regulated by intrinsic mechanisms (Schlatt et al. 2010), maturation of testis xenografts from horses (Rathi et al. 2006) and rhesus monkeys (Rathi et al. 2008, Ehmcke et al. 2011) is primarily regulated by the HPG axis and is therefore susceptible to exogenous modulation. In horses, application of gonadotropins (equine chorionic gonadotropin and human chorionic gonadotropin $(\mathrm{hCG})$ ) to recipient mice resulted in increased germ cell differentiation in testis xenografts (Rathi et al. 2006). Similarly, treatment of mice with hCG resulted in enhanced growth and endocrine function (Ehmcke et al. 2011) and advanced maturation (Rathi et al. 2008) of testis xenografts from infant monkeys. However, different to mice carrying testis grafts from horses and monkeys (Rathi et al. 2006, 2008), recipient mice with bovine testis grafts have larger than normal seminal vesicles (Rathi et al. 2005, Rodriguez-Sosa et al. 2011b) when compared to those reported for noncastrated controls (Schlatt et al. 2003). Seminal vesicles are androgen dependent (Schlatt et al. 2003), and their size is routinely used to evaluate the endocrine activity of testis xenografts (Rodriguez-Sosa \& Dobrinski 2009). Larger seminal vesicles in recipient mice with bovine tissue compared to those in mice receiving testis tissue from other species indicated that an excess of androgens, rather than a lack of gonadotropin support, could be involved in the poor maturation of bovine testis xenografts. Therefore, we hypothesized that treatment of recipient mice with the $\mathrm{GnRH}$ antagonist acyline to partially decrease androgen production of bovine xenografts (Shetty et al. 2006) would affect development and spermatogenic efficiency. A second hypothesis focused on the role of thyroid function in testis development and evaluated the use of 6-N-propyl-2-thiouracil (PTU). In rats, induction of transient hypothyroidism by PTU supplementation during the infantile period delayed Sertoli cell maturation and extended their proliferation, resulting in an increased number of Sertoli cells, sperm output, and adult testis size (Kirby et al. 1992, Hess et al. 1993, De Franca et al. 1995). In cattle, levels of $T_{3}$ and tetraiodothyronine $\left(\mathrm{T}_{4}\right)$ are negatively correlated to testicular volume (Majdic et al. 1998), suggesting that bovine testis tissue may be sensitive to modifications of thyroid hormone profiles of recipient mice. Therefore, the aim of the current study was to evaluate the effect of exogenous application of acyline and PTU in recipient mice on maturation and spermatogenesis of testis tissue from newborn calves.

\section{Results \\ Acyline experiment}

\section{Recovery and endocrine activity of xenografts}

Recipient mice were treated with acyline or left as controls. In total, $98.3 \%(417 / 424)$ of testis fragments originally transplanted were recovered as xenografts; 99.5\% (199/200) from controls; and 97.3\% (218/224) from treated mice $(P>0.05)$. Xenograft weight in the control mice was significantly higher than in the acylinetreated mice; $56.2 \pm 10.7$ vs $37.1 \pm 3.9 \mathrm{mg}$ respectively $(P<0.05)$. Seminal vesicle weight in treated recipient 
mice was also lower than in control mice $(177.8+7.8$ vs $403.9 \pm 30.6 \mathrm{mg}$ respectively; $P<0.05$ ), suggesting a lower concentration of bioactive androgens.

\section{Germ cell differentiation and development}

At the time of grafting, testis tissue from donor calves was typical for the newborn age, with seminiferous cords composed of gonocytes surrounded by immature Sertoli cells (Fig. 1A). On average, $57.2 \pm 3.9 \%$ of cords cross sections contained Sertoli cells only, while the rest contained gonocytes and spermatogonia $(40.1 \pm 8.7$ and $2.7 \pm 0.9 \%$ respectively). At collection, xenografts displayed evidence of postnatal development; presence of lumen, increased tubule diameter, and presence of differentiating germ cells (Fig. 1B and C). The seminiferous cord diameter in donors $(44.3 \pm 0.9 \mu \mathrm{m})$ increased in cords and tubules of xenografts from control (136.2 $\pm 2.1 \mu \mathrm{m})$ and acyline-treated $(130.9 \pm 1.9 \mu \mathrm{m})$ mice. There was a significant difference between donor and xenograft values $(P<0.05)$, but not between treatments. When germ cell differentiation was evaluated, xenografts showed a reduction in the number of tubules with Sertoli cells only and an increase in those with spermatogonia compared to donors $(P<0.05)$, but there was no effect of treatment (Table 1). Similarly, there was no effect of treatment on the number of tubules with primary spermatocytes $(P>0.05)$. However, acyline exposure
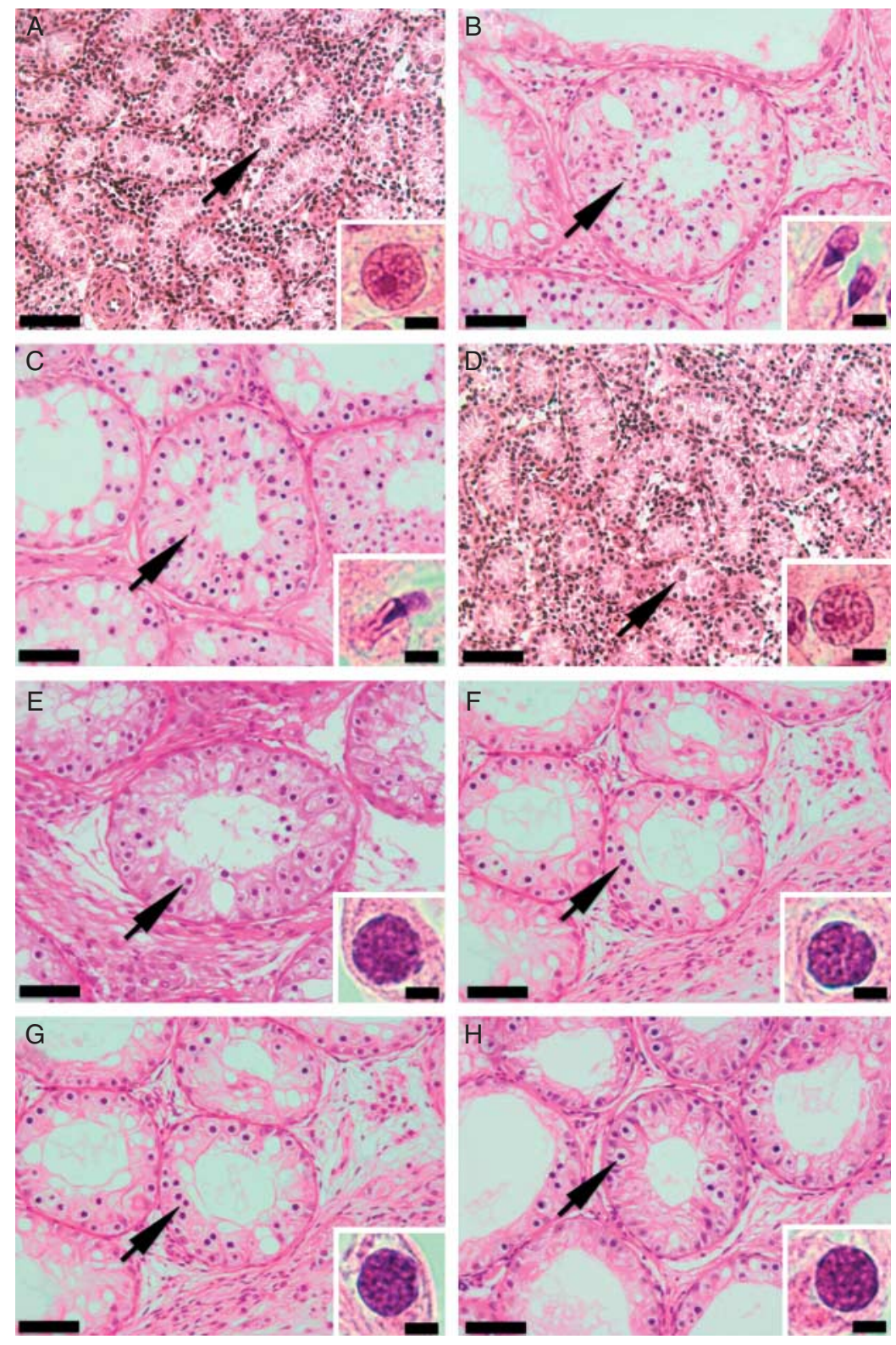

Figure 1 Histological appearance of donor testis tissue and testis xenografts from the acyline and PTU experiments. (A) Testis tissue from 1-week-old Holstein calves used as donors for the acyline experiment. (B) Testis xenograft collected from the control mice of the acyline experiment at 7 months. (C) Testis xenograft collected from the acyline-treated mice at 7 months. (D) Testis tissue from 1-week-old Holstein calves used as donors for the PTU experiment. (E) Testis xenograft collected from the control mice of the PTU experiment at 5 months. (F) Testis xenograft collected from the PTU-treated mice at 5 months. (G) Testis xenograft collected from the control mice of the PTU experiment at 7 months. (H) Testis xenograft collected from the PTU-treated mice at 7 months. Arrows point to the most advanced type of germ cell present in the seminiferous cords of donors and tubules of testis xenografts, which are also shown in insets. Gonocytes were the most advanced type of germ cells in donors (A and D), while elongated spermatids were the most advanced germ cells in xenografts from the acyline experiment (B and $\mathrm{C}$ ) and pachytene spermatocytes in xenografts from the PTU experiment $(\mathrm{E}, \mathrm{F}, \mathrm{G}$ and $\mathrm{H}$ ). Bars $=50$ and $5 \mu \mathrm{m}$ in panels and insets respectively. 
Table 1 Germ cell differentiation in testis xenografts in both acyline and 6-N-propyl-2-thiouracil (PTU) experiments.

\begin{tabular}{|c|c|c|c|c|c|c|c|c|}
\hline \multirow[b]{3}{*}{ Germ cell type } & \multicolumn{3}{|c|}{ Acyline experiment } & \multicolumn{5}{|c|}{ PTU experiment } \\
\hline & \multirow[b]{2}{*}{ Donor } & \multicolumn{2}{|c|}{ 7-Month xenografts } & \multirow[b]{2}{*}{ Donor } & \multicolumn{2}{|c|}{ 5-Month xenografts } & \multicolumn{2}{|c|}{ 7-Month xenografts } \\
\hline & & Control & Acyline & & Control & PTU & Control & PTU \\
\hline Sertoli cell only & $57.2 \pm 3.9^{\mathrm{A}}$ & $31.2 \pm 8.4^{\mathrm{B}}$ & $45.0 \pm 6.1^{\mathrm{B}}$ & $36.8 \pm 4.4^{\mathrm{A}}$ & $38.8 \pm 3.3^{\mathrm{A}}$ & $40.9 \pm 3.6^{\mathrm{A}}$ & $16.8 \pm 2.9^{B}$ & $27.5 \pm 3.2^{\mathrm{C}}$ \\
\hline Gonocytes & $40.1 \pm 8.7$ & - & - & $61.1 \pm 1.5$ & - & - & - & - \\
\hline Spermatogonia & $2.7 \pm 0.9^{\mathrm{A}}$ & $41.2 \pm 8.6^{\mathrm{B}}$ & $36.9 \pm 9.9^{\mathrm{B}}$ & $2.2 \pm 0.5^{\mathrm{A}}$ & $43.2 \pm 5.7^{\mathrm{B}}$ & $49.8 \pm 3.9^{\mathrm{B}}$ & $53.2 \pm 7.3^{\mathrm{B}}$ & $49.1 \pm 9.7^{\mathrm{B}}$ \\
\hline Pachytene spermatocytes & - & $24.4 \pm 7.7$ & $16.4 \pm 8.2$ & - & $17.8 \pm 3.1^{\mathrm{A}}$ & $9.3 \pm 4.9^{B}$ & $29.9 \pm 9.2^{\mathrm{C}}$ & $23.5 \pm 7.1^{\mathrm{C}}$ \\
\hline Round spermatids & - & $2.2 \pm 0.4^{\mathrm{A}}$ & $1.5 \pm 0.2^{\mathrm{B}}$ & - & - & - & - & - \\
\hline Elongated spermatids & - & $1.2 \pm 0.5^{\mathrm{A}}$ & $0.1 \pm 0.1^{\mathrm{B}}$ & - & - & - & - & - \\
\hline
\end{tabular}

Values represent the percentage (mean \pm s.E.M.) of seminiferous cord/tubule cross sections with the most advanced type of germ cell present. Within experiment, different letters denote statistical difference between columns.

resulted in a significant reduction of tubules with both round and elongated spermatids $(P<0.05)$.

\section{Stereological analysis}

In comparison to donor tissue, the volume density of the tubular compartment was increased in xenografts. However, only the xenografts collected from control mice were different to those of donors $(P<0.05$; Table 2$)$. In the tubular compartment, there was no difference in the volume densities of seminiferous epithelium, tunica propria, and lumen between xenografts from control and acyline-treated mice $(P>0.05)$. The Sertoli cell number, Sertoli cell volume, and seminiferous tubule length in xenografts from control mice were higher than in xenografts from acyline-treated mice $(P<0.05)$. In the intertubular compartment, the volume density of Leydig cells in xenografts from control mice was higher than in xenografts from acyline-treated mice $(P<0.05)$. The volume density of connective tissue was significantly reduced in xenografts compared to donors $(P<0.05)$, but there was no difference between xenografts groups $(P>0.05)$. However, the volume density of blood vessels was not different between donors and xenografts from control mice, but this parameter was lower in xenografts from acyline-treated mice $(P<0.05)$. There was no difference in the Leydig cell number between xenografts groups $(P>0.05)$, but Leydig cell volume was higher in xenografts from control mice than in those from treated mice $(P<0.05)$.

\section{Number of germ cells}

Donor and xenograft sections were immunostained for the gonocyte and spermatogonia marker ubiquitin carboxy-terminal hydrolase L1 (UCH-L1; Fig. 2A, B and $\mathrm{C}$ ). The number of cross sections with $\mathrm{UCH}-\mathrm{L} 1$ positive cells was $52.4 \pm 15.1,42.4 \pm 6.3$, and $41.2 \pm$ $6.4 \%$ in donors, control, and acyline-treated xenografts respectively $(P>0.05)$. When the number of UCH-L1positive cells was quantified in those cross sections, the number of these cells was lower in donors than in xenografts $(P<0.05)$, but no difference was observed between xenografts from control and acyline-treated mice. Donor tissue and xenografts from control and acyline-treated mice contained $1.2 \pm 1.7,7.7 \pm 0.7$, and $6.1 \pm 0.7 \mathrm{UCH}-\mathrm{L} 1$-positive cells per cross section respectively. Similarly, when the number of Sertoli cells in the cross sections was considered, the number of UCH-L1-positive cells per 100 Sertoli cells was lower in

Table 2 Stereological evaluation of donor testes and testis xenografts of the acyline experiment.

\begin{tabular}{|c|c|c|c|}
\hline Parameter & Donor & Control & Acyline \\
\hline Tubular compartment (\%) & $65.1 \pm 3.4^{\mathrm{A}}$ & $75.3 \pm 1.1^{\mathrm{B}}$ & $70.8 \pm 1.8^{\mathrm{A}, \mathrm{B}}$ \\
\hline Seminiferous epithelium (\%) & $43.4 \pm 3.3$ & $51.4 \pm 2.1$ & $45.6 \pm 2.2$ \\
\hline Tunica propria & $21.7 \pm 0.7^{\mathrm{A}}$ & $9.4 \pm 0.7^{\mathrm{B}}$ & $9.9 \pm 0.7^{\mathrm{B}}$ \\
\hline Seminiferous tubule lumen (\%) & - & $14.5 \pm 2.2$ & $15.3 \pm 1.1$ \\
\hline Sertoli cell number $\left(10^{6}\right)^{a}$ & $1.1 \pm 0.0^{\mathrm{A}}$ & $5.7 \pm 0.7^{\mathrm{B}}$ & $4.1 \pm 0.4^{\mathrm{C}}$ \\
\hline Sertoli cell volume $\left(\mu \mathrm{m}^{3}\right)$ & $94.3 \pm 3.7^{\mathrm{A}}$ & $478.3 \pm 11.2^{\mathrm{B}}$ & $406.9 \pm 24.2^{\mathrm{C}}$ \\
\hline Seminiferous cord or tubule length $(\mathrm{cm})^{\mathrm{a}}$ & $42.2 \pm 0.3^{\mathrm{A}}$ & $230.3 \pm 29.8^{\mathrm{B}}$ & $149.7 \pm 9.9^{\mathrm{C}}$ \\
\hline Intertubular compartment (\%) & $34.9 \pm 3.4^{\mathrm{A}}$ & $24.7 \pm 1.1^{\mathrm{B}}$ & $29.2 \pm 1.8^{\mathrm{A}, \mathrm{B}}$ \\
\hline Leydig cell $(\%)$ & $1.5 \pm 0.1^{\mathrm{A}}$ & $2.6 \pm 0.3^{\mathrm{B}}$ & $1.8 \pm 0.2^{\mathrm{A}}$ \\
\hline Connective tissue $(\%)$ & $32.7 \pm 3.4^{\mathrm{A}}$ & $21.0 \pm 1.3^{\mathrm{B}}$ & $25.8 \pm 1.2^{\mathrm{B}}$ \\
\hline Blood vessels (\%) & $0.6 \pm 0.0^{\mathrm{A}}$ & $0.7 \pm 0.05^{\mathrm{A}}$ & $0.4 \pm 0.03^{\mathrm{B}}$ \\
\hline Leydig cell number $\left(10^{6}\right)^{\mathrm{a}}$ & $0.1 \pm 0.1^{\mathrm{A}}$ & $1.8 \pm 0.3^{\mathrm{B}}$ & $1.3 \pm 0.2^{\mathrm{B}}$ \\
\hline Leydig cell volume $\left(\mu \mathrm{m}^{3}\right)$ & $114.9 \pm 5.9^{\mathrm{A}}$ & $643.7 \pm 22.9^{\mathrm{B}}$ & $417.1 \pm 20.4^{\mathrm{C}}$ \\
\hline
\end{tabular}

For each parameter, values represent the percentage (mean \pm S.E.M.). Different letters between columns denote statistical difference $(P<0.05)$.

an donors, values are total numbers in the original pieces of tissue used for transplantation. 

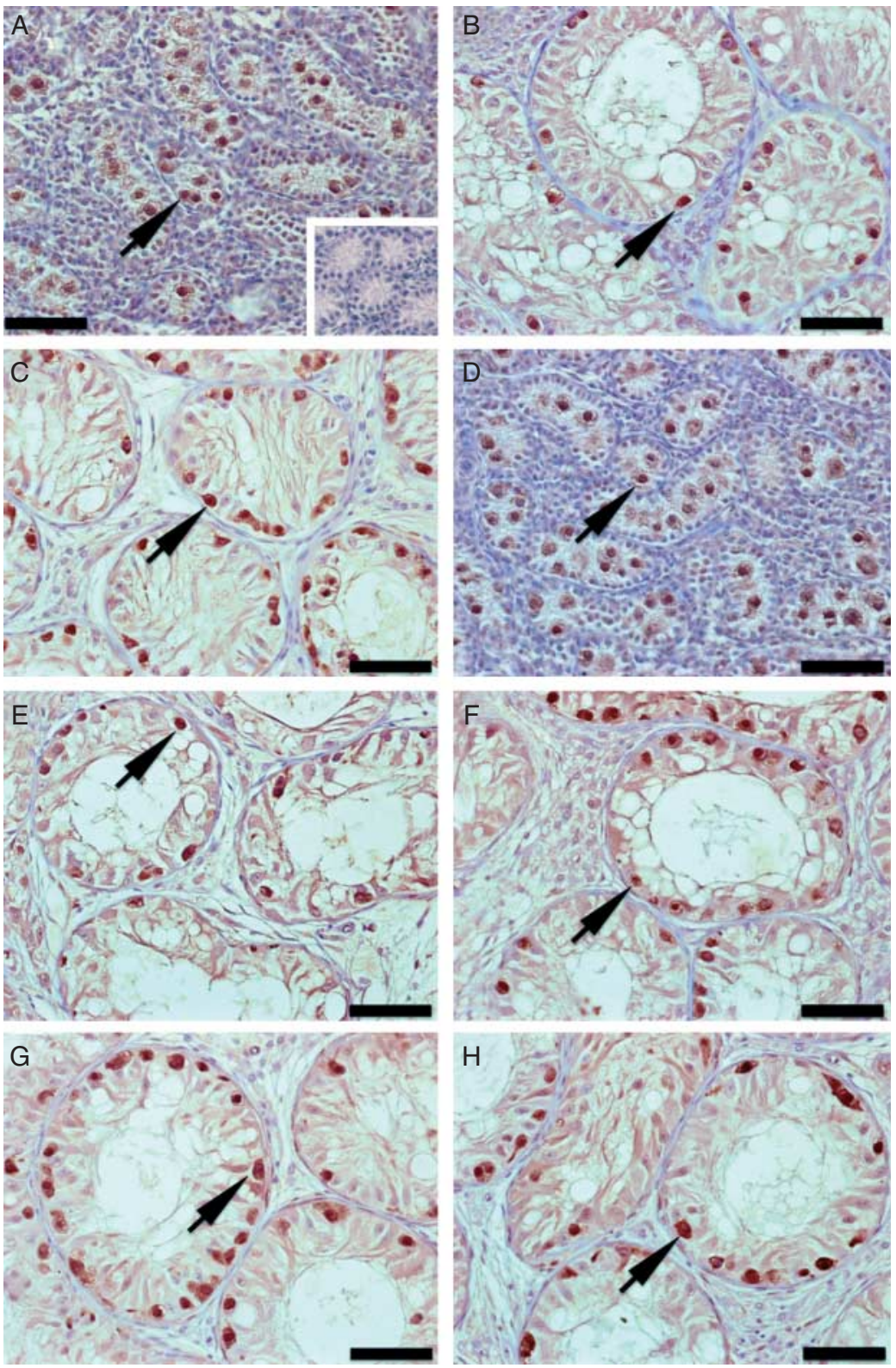

Figure 2 Immunohistochemistry for the gonocyte and spermatogonia marker UCH-L1 in donor testis tissue and testis xenografts from the acyline and PTU experiments. (A) Testis tissue from 1-week-old Holstein calves used as donors for the acyline experiment. Inset: negative control, same donor testis tissue with omission of primary antibody. (B) Testis xenograft collected from control mice of the acyline experiment at 7 months. (C) Testis xenograft collected from the acyline-treated mice at 7 months. (D) Testis tissue from 1 -week-old Holstein calves used as donors for the PTU experiment. (E) Testis xenograft collected from control mice of the PTU experiment at 5 months. (F) Testis xenograft collected from PTU-treated mice at 5 months. (G) Testis xenograft collected from the control mice of PTU experiment at 7 months. (H) Testis xenograft collected from PTU-treated mice at 7 months. Arrows point to UCH-L1-positive cells. $\mathrm{Bar}=50 \mu \mathrm{m}$. donors than in xenografts $(P<0.05)$, but no difference was observed between the xenografts from control and acyline-treated mice. Donor tissue and xenografts from control and acyline-treated mice contained $8.5 \pm 8.4$, $37.0 \pm 3.6$, and $34.9 \pm 3.9 \mathrm{UCH}-\mathrm{L} 1$-positive cells per 100 Sertoli cells respectively.

\section{Sertoli cell maturation}

In donor tissue, as expected for immature Sertoli cells, immunolocalization of Müllerian inhibiting substance (MIS) showed strong expression in the cytoplasm of Sertoli cells in $100 \%$ of the seminiferous cords (Fig. 3A). In the adult tissue control, MIS expression was absent (Figs 3A inset and 4A). Xenografts from the control and acyline-treated mice showed variable MIS expression in
$74.8 \pm 6.2$ and $79.3 \pm 6.3 \%$ of tubules respectively (Fig. 3B and C). There was no difference between donor and xenograft values or those of control and treated mice $(P>0.05)$. MIS staining intensity in donor tissue staining was higher than in xenografts $(P<0.05)$, but there was no difference between the xenografts from control and treated mice (Fig. 4B). Thus, based on MIS expression Sertoli cells underwent partial maturation.

Immunostaining for AR confirmed the partial maturation of Sertoli cells in xenografts. As expected, donor tissue showed complete absence of AR expression (Fig. 5A), whereas the adult control tissue showed strong expression in the Sertoli nuclei of $100 \%$ of the tubules (Figs 4A and 5A inset). In comparison to the adult control, xenografts from the control and acyline-treated mice showed lower AR expression in Sertoli cell nuclei 

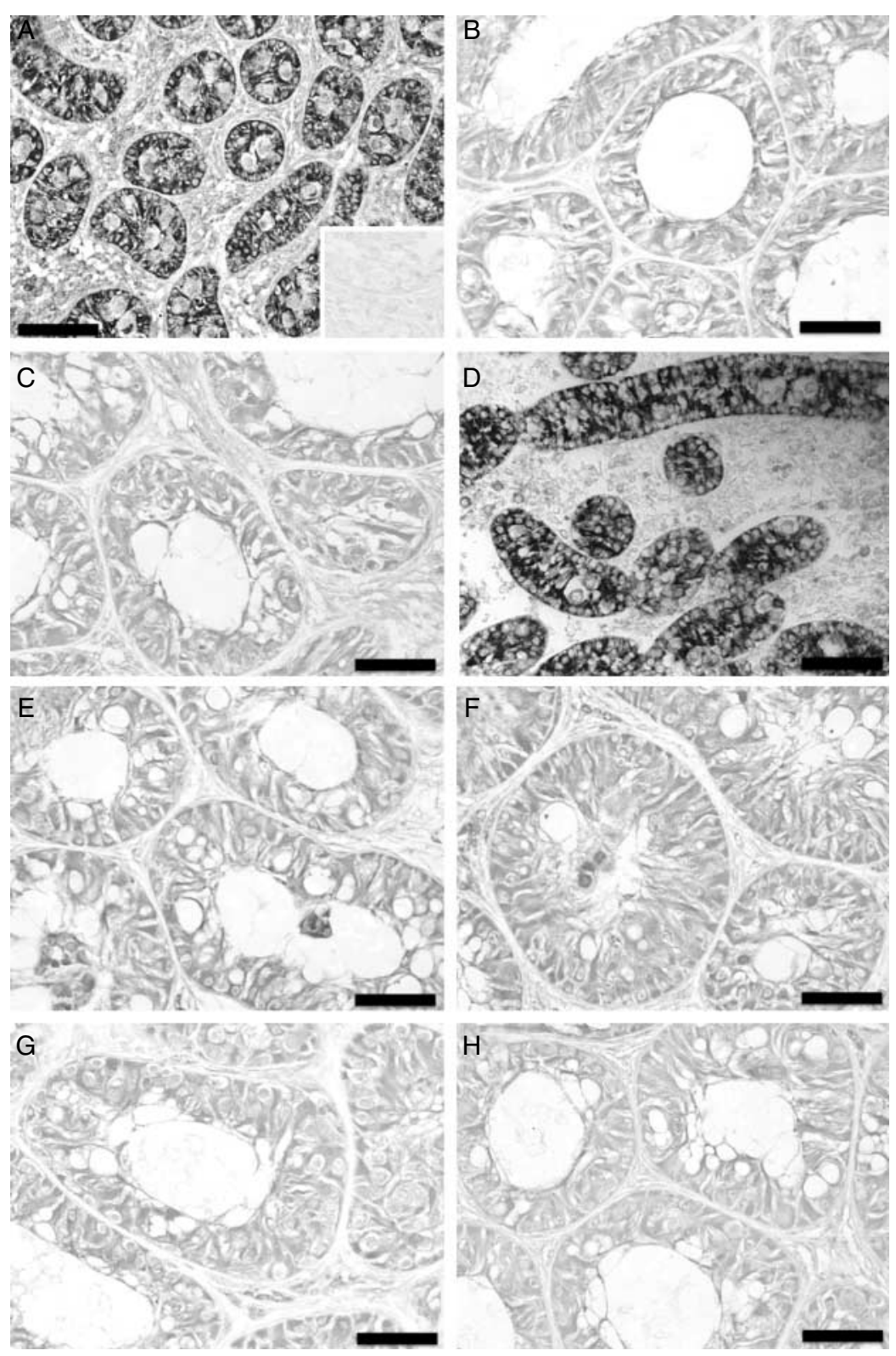

Figure 3 Immunohistochemistry for Müllerian inhibiting substance of donor testis tissue and testis xenografts from the acyline and PTU experiments.

(A) Testis tissue from 1-week-old Holstein calves used as donors for the acyline experiment. Inset: negative control adult testis tissue. (B) Testis xenograft collected from control mice of the acyline experiment at 7 months. (C) Testis xenograft collected from acylinetreated mice at 7 months. (D) Testis tissue from 1-week-old Holstein calves used as donors for the PTU experiment. (E) Testis xenograft collected from control mice of the PTU experiment at 5 months. (F) Testis xenograft collected from PTU-treated mice at 5 months. (G) Testis xenograft collected from control mice of the PTU experiment at 7 months. $(\mathrm{H})$ Testis xenograft collected from PTU-treated mice at 7 months. Bar $=50 \mu \mathrm{m}$. in $48.4 \pm 7.3$ and $42.8 \pm 7.3 \%$ of cross sections respectively (Fig. $5 B$ and C). Percentages of AR expressing tubules of both types of xenografts were not statistically different from each other, but significantly lower than in adult control $(P<0.05)$.

\section{PTU experiment}

\section{Recovery and endocrine activity of xenografts}

Recipient mice were treated with PTU in the drinking water for 4 weeks or left as controls. A preliminary experiment showed this treatment to result in a significant reduction of $\mathrm{T}_{3}$ in treated mice at 4 weeks of treatment (see Materials and Methods). Of the 236 testis fragments that were transplanted, 186 were recovered $(78.8 \%)$. At 5 months, $86.6 \%(52 / 60)$ of the xenografts were recovered from the control mice, while $97.5 \%(39 / 40)$ were collected from the PTU-treated mice. At 7 months $81.9 \%$ (59/72) of the xenografts from the control mice were recovered, while $56.3 \%(36 / 64)$ were harvested from the PTU-treated mice. While there was no effect of treatment in the percentage of recovered grafts at 5 months $(P>0.05)$, at 7 months the recovery in the PTU-treated mice was significantly lower than in control mice $(P<0.05)$. Xenograft weight at 5 months was higher in control mice than in the PTU-treated mice; $42.0 \pm 5.1$ vs $20.8 \pm 3.9 \mathrm{mg}$ respectively $(P<0.05)$. At 7 months, xenograft weight in the control mice was 51.1 $\pm 4.5 \mathrm{mg}$, and lower in the PTU-treated mice; 24.1 

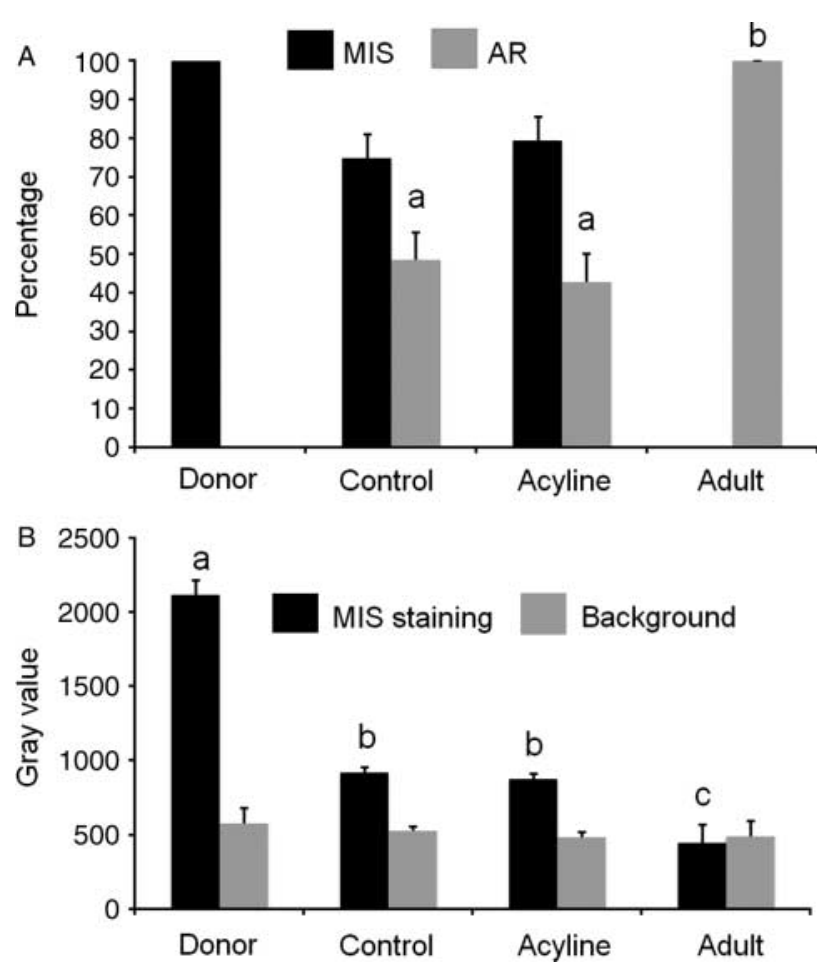

Figure 4 Percentage of seminiferous cord and tubule cross sections containing Müllerian inhibiting substance (MIS)- and androgen receptor-positive cells (A) and densitometry analysis of MIS expression in cords and tubules in donors testis and testis xenografts (B) of the acyline experiment. As adult control tissue was negative for MIS, note that in (B) in the adult sample the black bar represents the background staining of the seminiferous epithelium, while the gray bar represents only the background of the interstitial tissue. Different letters between bars of the same shade indicate significant difference $(P<0.05)$.

$\pm 8.8 \mathrm{mg}(P<0.05)$. However, the seminal vesicle weight in recipient mice was not different at any collection point $(P>0.05)$. At 5 months, seminal vesicle weight in the control mice was $374.2 \pm 37.8$ vs 385.3 $\pm 82.1 \mathrm{mg}$ in the PTU-treated mice. At 7 months, seminal vesicle weights were $401.3 \pm 35.9$ and $264.8 \pm 78.9 \mathrm{mg}$ in the control and PTU-treated mice respectively.

\section{Germ cell differentiation and development}

As above, donor testis tissue contained seminiferous cords with primitive germ cells and Sertoli cells (Fig. 1D). Sertoli cells only were present in $36.8 \pm 4.4 \%$ of cords cross sections. Gonocytes and spermatogonia were evident in $61.0 \pm 1.5$ and $2.2 \pm 0.5 \%$ respectively (Table 1). In xenografts, tubule development occurred, seminiferous cords/tubules increased in size, and meiotic germ cells were the most advanced type of germ cells (Fig. 1E, F, G and H). The seminiferous cord diameter increased from $47.1 \pm 0.7$ in donors to 139.9 \pm 6.9 and $121.2 \pm 2.9 \mu \mathrm{m}$ in 5 -month xenografts of the control and PTU-treated mice respectively. In 7-month xenografts, tubule diameter increased further to 170.3 \pm 2.2 and $143.7 \pm 2.3 \mu \mathrm{m}$ in xenografts of the control and PTU-treated mice respectively. Xenograft values at 5 and 7 months were different by treatment and significantly higher than in donor tissue. Values for xenografts from control mice were significantly higher than those of PTU-treated mice $(P<0.05)$. In comparison to donor tissue, xenografts collected at 5 months did not show a difference in the number of tubules with Sertoli cells only, but this number decreased in xenografts collected at 7 months. At this collection point the value for xenografts from control mice was lower than that for xenografts from PTU-treated mice $(P<0.05)$. The number of tubules with spermatogonia increased in xenografts compared to donor tissue $(P<0.05)$, but not between 5 and 7 months. However, the number of tubules with primary spermatocytes significantly increased in xenografts from 5 to 7 months, and while at 5 months PTU treatment resulted in a lower number of tubules with spermatocytes $(P<0.05)$, at 7 months there was no effect of treatment.

\section{Stereological analysis}

The volume density of the tubular compartment was increased in xenografts in comparison to donors, except in the xenografts collected at 5 months from the PTUtreated mice (Table 3, $P<0.05$ ). The density of the tubular compartment was lower in xenografts from PTUtreated mice collected at 5 months than in the other xenografts groups $(P<0.05)$. In the tubular compartment, in comparison to donors, the density of the seminiferous epithelium was only increased in xenografts collected at 7 months from the PTU-treated mice $(P<0.05)$. However, there was no difference between xenograft groups $(P>0.05)$. At each collection point, the number of Sertoli cells was higher in xenografts from control mice than in those from treated mice $(P<0.05)$. In xenografts from control mice the number of Sertoli cells was lower at 5 months than at 7 months $(P<0.05)$. Sertoli cell volume was also higher in xenografts from control mice than in those from PTU-treated mice at both collection points $(P<0.05)$. In addition, in both groups of xenografts, Sertoli cell volume was lower at 5 months than at 7 months $(P<0.05)$. The seminiferous tubule length was higher in xenografts from control mice than in those from PTU-treated mice $(P<0.05)$. In the intertubular compartment, there was no difference in the volume density of Leydig cells between donors and xenografts nor between xenograft groups $(P>0.05)$. The connective tissue density, blood vessels density, and Leydig cell number were not different between xenografts from control and PTU-treated mice $(P>0.05)$. However, Leydig cell volume at each collection point was higher in xenografts from control mice than in those from treated mice $(P<0.05)$. Moreover, in xenografts from control mice the Leydig cell volume was lower at 5 months than at 7 months $(P<0.05)$. 

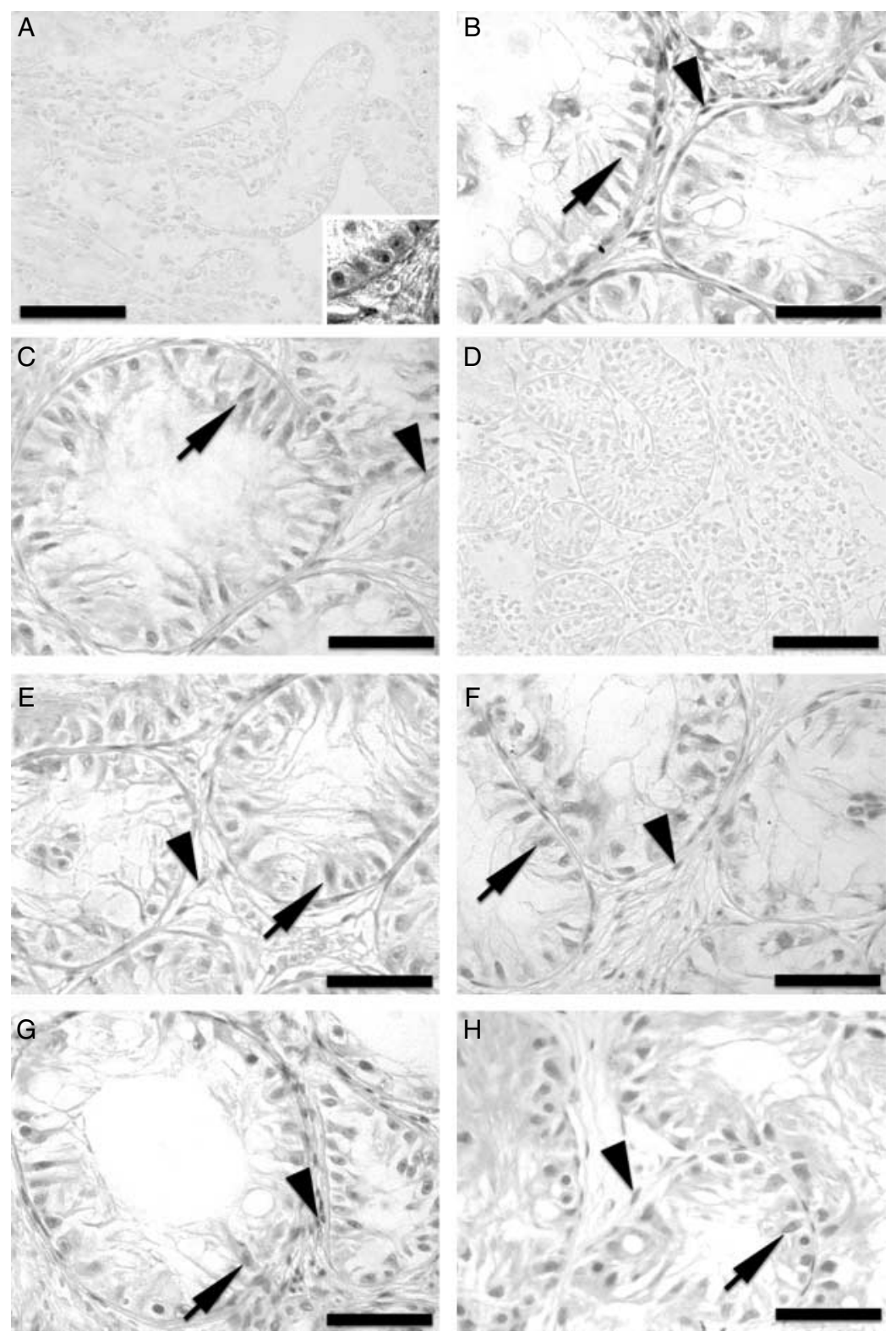

Figure $5 \mathrm{Immunohistochemistry} \mathrm{for} \mathrm{androgen} \mathrm{receptor}$ (AR) of donor testis tissue and testis xenografts from the acyline and PTU experiments. (A) Testis tissue from 1-week-old Holstein calves used as donors for the acyline experiment. Inset: positive control adult testis tissue. (B) Testis xenograft collected from the control mice of the acyline experiment at 7 months. (C) Testis xenograft collected from the acyline-treated mice at 7 months. (D) Testis tissue from 1-week-old Holstein calves used as donors for the PTU experiment.

(E) Testis xenograft collected from the control mice of the PTU experiment at 5 months. (F) Testis xenograft collected from the PTU-treated mice at 5 months. (G) Testis xenograft collected from the control mice of the PTU experiment at 7 months. $(\mathrm{H})$ Testis xenograft collected from the PTU-treated mice at 7 months. Arrows point to AR-positive Sertoli cells, while arrowheads point to AR-positive interstitial cells. Bar $=50 \mu \mathrm{m}$.

\section{Number of germ cells}

Donor and xenograft sections were immunostained for UCH-L1 (Fig. 2D, E, F, G and H). At 5 months, the number of cross sections with UCH-L1-positive cells in xenografts from control and PTU-treated mice (48.7 \pm 5.4 and $39.2 \pm 6.7 \%$ respectively) was significantly lower than in donors $(70.3 \pm 4.4 \% ; P<0.05)$, but not different from each other. However, at 7 months xenograft values were not different from donor tissue or from each other; $77.8 \pm 3.24$ and $73.5 \pm 6.3 \%$ in control and PTU-treated mice respectively $(P>0.05)$. At 5 and 7 months the number of UCH-L1-positive cells per cross section was significantly higher in xenografts than in donors $(P<0.05)$, but there was no effect of treatment.
At 5 months, donor tissue and xenografts from control and PTU-treated mice contained $1.5 \pm 0.4,7.6 \pm 0.5$, and $5.7 \pm 0.6 \mathrm{UCH}-\mathrm{L} 1$-positive cells per cross section respectively. The number of $\mathrm{UCH}$-L1-positive cells per 100 Sertoli cells was also higher in xenografts than in donors $(P<0.05)$, but there was no effect of treatment. Donor tissue and xenografts from control and PTUtreated mice contained $11.9 \pm 2.6,32.7 \pm 3.0$, and $25.8 \pm 3.6 \mathrm{UCH}-\mathrm{L} 1$-positive cells per 100 Sertoli cells respectively. At 7 months, xenografts from control and PTU-treated mice contained $7.2 \pm 0.9$ and $5.7 \pm 0.6$ UCH-L1-positive cells per cross section, and 46.9 \pm 3.4 and $39.9 \pm 6$ positive cells per 100 Sertoli cells respectively. 
Table 3 Stereological evaluation of donor testes and testis xenografts of the 6-N-propyl-2-thiouracil (PTU) experiment.

\begin{tabular}{|c|c|c|c|c|c|}
\hline \multirow[b]{2}{*}{ Parameter } & \multirow[b]{2}{*}{ Donor } & \multicolumn{2}{|c|}{ 5-Month xenografts } & \multicolumn{2}{|c|}{ 7-Month xenografts } \\
\hline & & Control & PTU & Control & PTU \\
\hline Tubular compartment (\%) & $55.6 \pm 2.2^{\mathrm{A}}$ & $76.3 \pm 2.1^{\mathrm{B}}$ & $63.3 \pm 6.2^{\mathrm{A}}$ & $75.1 \pm 3.1^{\mathrm{B}}$ & $74.3 \pm 2.2^{\mathrm{B}}$ \\
\hline Seminiferous epithelium (\%) & $34.5 \pm 2.1^{\mathrm{A}}$ & $44.9 \pm 3.1^{\mathrm{A}, \mathrm{B}}$ & $43.2 \pm 5.1^{\mathrm{A}, \mathrm{B}}$ & $40.3 \pm 3.3^{\mathrm{A}, \mathrm{B}}$ & $51.2 \pm 3.3^{\mathrm{B}}$ \\
\hline Tunica propia (\%) & $21.1 \pm 0.6^{\mathrm{A}}$ & $12.2 \pm 0.6^{\mathrm{B}}$ & $11.1 \pm 0.9^{\mathrm{B}}$ & $10.9 \pm 0.5^{\mathrm{B}}$ & $11.7 \pm 0.7^{\mathrm{B}}$ \\
\hline Seminiferous tubule lumen (\%) & - & $19.2 \pm 3.1^{\mathrm{A}}$ & $9.0 \pm 2.0^{\mathrm{B}}$ & $23.9 \pm 4.2^{\mathrm{A}}$ & $11.4 \pm 1.2^{\mathrm{B}}$ \\
\hline Sertoli cell number $\left(\times 10^{6}\right)^{\mathrm{a}}$ & $0.98 \pm 0.03^{\mathrm{A}}$ & $5.3 \pm 0.4^{\mathrm{B}}$ & $3.2 \pm 0.2^{\mathrm{C}}$ & $6.5 \pm 0.1^{\mathrm{D}}$ & $3.5 \pm 0.1^{\mathrm{C}}$ \\
\hline Sertoli cell volume $\left(\mu \mathrm{m}^{3}\right)$ & $104.9 \pm 3.0^{\mathrm{A}}$ & $440.3 \pm 19.2^{B}$ & $341.2 \pm 14.1^{\mathrm{C}}$ & $504.2 \pm 6.3^{\mathrm{D}}$ & $388.0 \pm 18.2^{\mathrm{E}}$ \\
\hline $\begin{array}{l}\text { Seminiferous cord or tubule length } \\
(\mathrm{cm})^{\mathrm{a}}\end{array}$ & $32.1 \pm 2.0^{\mathrm{A}}$ & $209.9 \pm 20.1^{B}$ & $120.2 \pm 10.1^{\mathrm{C}}$ & $170.4 \pm 30.3^{B}$ & $110.2 \pm 29.9^{C}$ \\
\hline Intertubular compartment (\%) & $44.4 \pm 2.2^{\mathrm{A}}$ & $23.7 \pm 2.1^{\mathrm{B}}$ & $36.7 \pm 6.2^{\mathrm{A}}$ & $24.9 \pm 3.1^{\mathrm{B}}$ & $25.7 \pm 2.2^{\mathrm{B}}$ \\
\hline Leydig cell (\%) & $1.9 \pm 0.2$ & $2.7 \pm 0.3$ & $3.4 \pm 0.4$ & $2.7 \pm 0.5$ & $2.1 \pm 0.4$ \\
\hline Connective tissue $(\%)$ & $41.6 \pm 1.9^{\mathrm{A}}$ & $20.6 \pm 2.1^{\mathrm{B}}$ & $27.4 \pm 5.2^{\mathrm{B}}$ & $21.7 \pm 3.1^{\mathrm{B}}$ & $22.9 \pm 2.1^{\mathrm{B}}$ \\
\hline Blood vessels (\%) & $0.8 \pm 0.1^{\mathrm{A}}$ & $0.3 \pm 0.03^{\mathrm{B}}$ & $0.4 \pm 0.04^{\mathrm{B}}$ & $0.4 \pm 0.05^{\mathrm{B}}$ & $0.3 \pm 0.03^{B}$ \\
\hline Leydig cell number $\left(\times 10^{6}\right)^{\mathrm{a}}$ & $0.2 \pm 0.02^{\mathrm{A}}$ & $1.3 \pm 0.1^{\mathrm{B}}$ & $1.0 \pm 0.1^{\mathrm{B}}$ & $1.5 \pm 0.2^{\mathrm{B}}$ & $0.9 \pm 0.1^{\mathrm{B}}$ \\
\hline Leydig cell volume $\left(\mu \mathrm{m}^{3}\right)$ & $111.2 \pm 5.3^{\mathrm{A}}$ & $799.3 \pm 33.9^{\mathrm{B}}$ & $576.6 \pm 19.3^{C}$ & $895.2 \pm 56.1^{\mathrm{D}}$ & $557.2 \pm 16.9^{\mathrm{C}}$ \\
\hline
\end{tabular}

For each parameter, values represent the percentage (mean \pm s.E.M.). Different letters between columns denote statistical difference $(P<0.05)$.

an donors, values are total numbers in the original pieces of tissue used for transplantation.

\section{Sertoli cell maturation}

As above, donor tissue showed strong MIS expression in the cytoplasm of Sertoli cells in $100 \%$ of the seminiferous cords (Figs 3D and 6A). At 5 months, variable MIS expression was present also in $100 \%$ of tubules of xenografts from both control and PTU-treated mice (Fig. 3E and F). As expected, therefore, there was no statistical difference between donor and xenografts values or between xenografts. At 7 months, MIS expression was observed in $87.5 \pm 6.2$ and $88.8 \pm 7.2 \%$ of the cords and tubules in xenografts from the control and PTU-treated mice respectively (Fig. 3G and $\mathrm{H}$ ). There was no statistical difference between the xenografts from both collection points or between those from control and treated mice $(P>0.05)$. Intensity of MIS staining in donor tissue was significantly higher than in xenografts of any collection point or group of recipient mice $(P<0.05)$, but there was no difference between the xenografts from both collection points or between those from control and treated mice (Fig. 6B).

Donor tissue showed complete absence of $A R$ expression (Figs 5D and 6A). At 5 months, xenografts from the control and PTU-treated mice showed AR expression in $67.2 \pm 16.6$ and $15.6 \pm 10.5 \%$ of tubule cross sections respectively (Fig. 5E and F). At 7 months, there was AR expression in $63.4 \pm 10.5$ and 11.7 $\pm 11.2 \%$ of tubule cross sections of xenografts from control and treated mice respectively (Fig. 5G and H). While at 5 months the number of tubules with AR expression was not different between xenografts from control and PTU-treated mice, at 7 months this number was lower in xenografts from treated mice. Moreover, at both collection points the xenografts from PTU-treated mice were different to the adult control (which showed $100 \%$ of tubules with AR expression) but not those from the control mice $(P<0.05)$.

\section{Discussion}

Testis tissue xenografting is a feasible approach to study testis development and spermatogenesis, and to preserve fertility in immature males in which sperm collection is not an option (Rodriguez-Sosa \& Dobrinski 2009, Jahnukainen et al. 2011, Rodriguez-Sosa et al. 2011a). Exogenous modulation of the endocrine environment of the rodent host expands the use of this technique as experimental tool. To date, exogenous hormone supplementation has been applied to improve maturation and spermatogenesis of testis xenografts (Rathi et al. 2006, 2008). Cattle are an important agricultural species, but the utility of testis tissue xenografting to obtain sperm is limited because maturation and spermatogenesis in bovine testis xenografts are inefficient when compared with those of other species (Rodriguez-Sosa \& Dobrinski 2009). In the current study, two treatment strategies were explored to modify the endocrine environment of recipient mice.

The first treatment focused on the HPG axis to test the hypothesis that increased testosterone production by bovine Leydig cells was involved in poor maturation and spermatogenesis of bovine testis xenografts. This was based on the observation that recipient mice with newborn and fetal bovine testis xenografts have larger seminal vesicles than those reported in noncastrated nude mice. In the latter, the seminal vesicle weight was reported to be $233.2 \pm 40.5 \mathrm{mg}$ (Schlatt et al. 2002), while in mice receiving newborn (Rathi et al. 2005, Schmidt et al. 2006) and fetal (Rodriguez-Sosa et al. $2011 b$ ) bovine testis tissue seminal vesicle weight was $>300 \mathrm{mg}$, and in some cases $>1 \mathrm{~g}$. Testosterone serum concentrations in nude mice used as recipients of testis tissue from 1- and 2-week-old calves (Schmidt et al. 2006) were higher when compared to those reported for noncastrated mice of the same strain (Schlatt et al. 2002), 

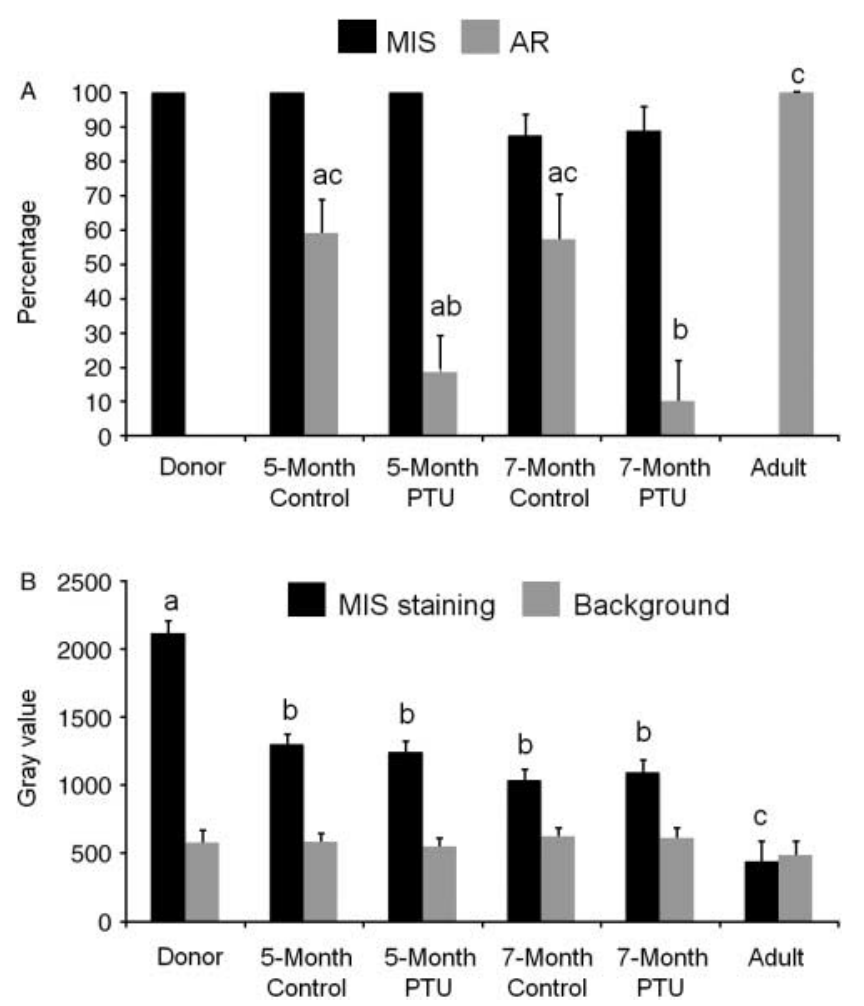

Figure 6 Percentage of seminiferous cord and tubule cross sections containing Müllerian inhibiting substance (MIS)- and androgen receptor-positive cells (A) and densitometry analysis of MIS expression in cords and tubules in donors testis and testis xenografts (B) of the PTU experiment. As adult control tissue was negative for MIS, note that in (B) in the adult sample the black bar represents the background staining of the seminiferous epithelium, while the gray bar represents only the background of the interstitial tissue. Different letters between bars of the same shade indicate significant difference $(P<0.05)$.

and higher or similar to those of 1 - to 12-month-old bulls (Rawlings et al. 1972). It appeared possible that Leydig cells in immature bovine testis tissue showed a heightened responsiveness to adult levels of gonadotropins in the mouse host. We therefore attempted to partially decrease the recipient gonadotropins and xenograft testosterone with acyline (Shetty et al. 2006). As expected, in treated mice xenograft weight and seminal vesicle weight were significantly lower than in control mice, indicating a decrease in androgen production by Leydig cells in xenografts (Schlatt et al. 2002). However, presence of postmeiotic cells was significantly reduced in xenografts from treated mice. In comparison to xenografts from treated mice, xenografts from control mice showed 1.4- and 12-fold more tubules with round and elongated spermatids respectively. Therefore, while treatment affected the endocrine function of bovine testis xenografts, this did not result in improvement of their maturation and germ cell differentiation.

The effect of acyline treatment on the endocrine activity and germ cell differentiation of testis tissue xenografts can be attributed to a reduction of gonadotropin support. Changes in Leydig cell morphology reflect differences in their function as a result of lower LH support, in line with the lower androgenic activity evidenced by the lower seminal vesicle weights in treated mice. While the number of Leydig cells was similar between xenografts of treated mice and controls, in treated mice the volume of Leydig cells was smaller. Effects of lower FSH supply were also evident. In xenografts from treated mice the number and volume of Sertoli cells were significantly lower than in xenografts from control mice. This in turn also resulted in lower seminiferous tubule length. Different androgen production by xenografts may have also contributed to these effects on the volume of Sertoli cells as testosterone together with FSH affects the functions of mature Sertoli cells (Sharpe et al. 2003). However, the effect of androgens on Sertoli cells may have been limited as AR expression was low. An unexpected result of the acyline experiment was the reduction in the percentage of blood vessels induced by treatment. As blood vessels were not quantified, it is unknown whether the observed effect reflected differences on the number and/or volume of blood vessels in xenografts. A difference in number of blood vessels could result from differences in gonadotropin stimulation, as gonadotropins influence angiogenesis after grafting of gonadal tissue (Paris et al. 2004). Moreover, LH regulates vasomotion of testicular blood vessels and acyline treatment may have resulted in lower volume of blood vessels in xenografts from treated mice (Welsh et al. 2010). Fewer or smaller blood vessels represent a lower supply of blood, nutrients, and hormones. Therefore, acyline effects may have also been mediated in part by a decrease in the number and/ or size of blood vessels in xenografts from treated mice. As acyline treatment affected FSH as well as $\mathrm{LH}$, it remains unclear whether an overproduction of testosterone is involved in failure of bovine testis xenograft development as originally hypothesized. However, the results demonstrated that, similar to horse (Rathi et al. 2006) and rhesus monkey (Rathi et al. 2008, Ehmcke et al. 2011), the development and endocrine function of bovine testis xenografts are primarily regulated by the HPG axis and exogenous modulation of the HPG axis is possible, leading to measurable effects on tissue development and germ cell differentiation of xenografts.

In the second experiment we focused on the thyroidtestis interaction. We induced transient hypothyroidism in recipient mice expecting to increase the number of Sertoli cells by retarding their maturation. In rats, treatment with PTU from birth to 25-day postpartum (pp) resulted in increased testicular size and daily sperm production in adults (Hess et al. 1993). This was attributed to delayed maturation of Sertoli cells, allowing proliferation to occur beyond 15-day pp (De Franca et al. 1995, Sharpe et al. 2003), which is closely related to the time when the first meiotic division starts 
(McCarrey 2003). Sertoli cell proliferation after xenografting of testis tissue has not been described in detail in bovine and other species. In a previous study we observed first appearance of primary spermatocytes in bovine testis xenografts after 2 months of grafting (Rathi et al. 2005), therefore, we treated only during the first month after surgery and collected the tissue at two time points. At 5 months, we expected to observe in xenografts from treated mice less mature Sertoli cells and lower germ cell differentiation than in those from control mice. At 7 months we hypothesized that xenografts from treated mice would have higher number of Sertoli cells, seminiferous tubule length, and number of seminiferous tubules with haploid germ cells. Interestingly, our observations did not support these hypotheses. For example, at both collection points the number and volume of Sertoli cells were lower in xenografts from treated mice than in those from controls, also resulting in shorter seminiferous tubules. Moreover, unlike in xenografts from control mice, the number of Sertoli cells in xenografts from treated mice was not different between 5 and 7 months. This indicates that under PTU influence Sertoli cells stopped proliferating earlier in treated mice than in controls, in which Sertoli cell proliferation occurred beyond 5 months. While the reasons for this cannot be determined from the current experiment, the length of PTU treatment may have been insufficient. It is possible that thyroid hormone concentrations resurged in recipient mice after PTU withdrawal, inducing Sertoli cells to stop proliferating earlier than in control xenografts. Important species differences have been reported in response to PTU. In pigs, PTU has an opposite effect to that observed in rodents (Cooke et al. 2005). However, in a previous study, an inverse relationship between neonatal $\mathrm{T}_{4}$ levels and pubertal testis size was found in bulls. Moreover, when marked neonatal hypothyroidism was induced by feeding rams and bulls with PTU, body and testis weights initially decreased and underwent compensatory growth as reported in rats, although adult testis size and sperm production were similar to those of controls (Cooke et al. 2005).

$\mathrm{T}_{3}$ stimulation occurring shortly after PTU withdrawal in xenografts from treated mice would explain the lower Sertoli cell number, but not the lower volume of these cells in this group of xenografts. Lower Sertoli cell volume suggests an immature state, which is opposite to the expected effect of $\mathrm{T}_{3}$ as this hormone also plays a role in maturation of Sertoli cells (Sharpe et al. 2003). While FSH promotes Sertoli cell proliferation, $\mathrm{T}_{3}$ induces their differentiation (Wagner et al. 2008). Both hormones promote Sertoli cell maturation, acting synergistically to induce AR expression. Androgens then contribute to the final functional and morphological maturation of Sertoli cells (Sharpe et al. 2003). A lack of synchrony in the action of $\mathrm{FSH}_{3} \mathrm{~T}_{3}$, and androgens may have contributed to the lower volume of Sertoli cells in xenografts from treated mice in comparison to those from controls. It has been shown that lower levels of $T_{3}$ also result in lower levels of gonadotropins (Wagner et al. 2008). PTU exposure could have also resulted in lower levels of $\mathrm{FSH}$ in recipient mice, and in turn contributed to both lower number and volume of Sertoli cells. However, smaller Sertoli cell volume may also be indicative of reduced function; mature mutant mice with a drastic decrease of germ cells show lower Sertoli cell volume in comparison to controls (De Franca et al. 1994). At 5 months, the number of tubules with spermatocytes in xenografts from control mice was approximately twofold greater than in xenografts from acyline-treated mice. Moreover, at 7 months the number of tubules with Sertoli cells only was approximately twofold greater in xenografts from acyline-treated mice than those from control mice. Reduction in the presence and differentiation of germ cells in xenografts from treated mice may have also contributed to the smaller Sertoli cell volume. Our results suggest that the thyroid-testis interaction is reestablished after ectopic transplantation of testis tissue in recipient mice, and that its exogenous modulation affects the development of bovine testis xenografts.

Low maturation and spermatogenesis in bovine xenografts are associated with meiotic arrest (Rathi et al. 2005, Rodriguez-Sosa et al. 2011b). The results obtained in the current study support this observation, especially those of the PTU experiment. In the acyline study, complete germ cell differentiation occurred, albeit in a low number of tubules. Differences in the level of germ cell differentiation between acyline and PTU experiments may be explained by a donor effect (Rathi et al. 2006). However, despite this difference, common findings regarding Sertoli cell maturation provide some insight into the causes behind the low efficiency of bovine testis xenografts. During puberty, as Sertoli cells mature, expression of MIS decreases while expression of AR reaches maximum levels at sexual maturity (Sharpe et al. 2003). In both acyline and PTU experiments, MIS expression significantly decreased in xenografts in comparison to donor levels, but did not reach that of adult control. On the other hand, AR expression was present but not at the adult tissue level. Although MIS and AR expression could overlap for a specific period, in the current study MIS expression persisted in bovine testis xenografts. In mouse testis (Al-Attar et al. 1997) and monkey testis xenografts (Rathi et al. 2008), MIS expression was absent in tubules that had undergone meiosis. In the current study however, in xenografts from control mice collected at 7 months, meiotic or postmeiotic germ cells were present in $27.8-30 \%$ of the tubules, while MIS was present in 74.8-87.5\%. This indicates that MIS expression occurred even in some tubules with germ cell differentiation. However, in transgenic mice overexpressing MIS spermatogenesis proceeds normally (Behringer et al. 1990). As MIS is downregulated primarily by testosterone through the AR 
(Al-Attar et al. 1997), persistent expression of MIS could be a consequence of low AR expression, which might be the primary cause of incomplete Sertoli cell maturation and germ cell differentiation in bovine testis xenografts. Accordingly, in the Sertoli cell-selective AR knockout mice poor germ cell differentiation occurs, with the majority of germ cell maturation ceasing at the diplotene primary spermatocyte stage (Chang et al. 2004), and a few secondary spermatocytes and round spermatids can be observed occasionally (De Gendt et al. 2004, Holdcraft \& Braun 2004). This suggests that a lack of androgen action rather than excess of it, as originally hypothesized, may be responsible for the meiotic arrest and incomplete Sertoli cell maturation of bovine testis xenografts. However, it is also possible that an excess of androgen production by Leydig cells results in alteration of AR expression in Sertoli cells. Additional studies are necessary to evaluate the involvement of AR and androgens in the failure of maturation and spermatogenesis of bovine testis xenografts.

In summary, the HPG axis and thyroid-testis interaction regulate maturation and endocrine function of bovine testis xenografts. Exogenous modulation of these endocrine regulations is possible, which opens new avenues for the use of testis tissue xenografting in research. In the current study, the use of acyline and PTU resulted in measurable effects on the development and function of testis xenografts, but not in improvement of their maturation and germ cell differentiation. Incomplete Sertoli cell maturation seems to be involved in lack of maturation and full germ cell differentiation of bovine xenografts. Further studies are required to determine the mechanisms behind this.

\section{Materials and Methods \\ Donor tissue and recipients}

Donor tissue was obtained from testes of 1-week-old Holstein calves, and 6- to 8-week-old NCR Nude mice were used as recipients (Taconic, Germantown, NY, USA). In total, five donors and $12 \mathrm{mice} /$ donor, and six donors and six mice/donor were used for the acyline and PTU experiments respectively. Pieces of donor tissue that was not transplanted were fixed in Bouin's solution, embedded in paraffin or plastic (glycol methacrylate, Leica Historesin; Leica Microsystems, Heidelberg, Germany) and processed for staining as described below. All animal procedures were in accordance with the University of Pennsylvania Institutional Animal Care and Use Committee.

\section{Ectopic xenografting}

Donor testes were cut into fragments of $\sim 1 \mathrm{~mm}^{3}$ ( $\sim 1 \mathrm{mg}$ each) that were placed into ice-cold DMEM (Invitrogen), and subsequently transplanted under the dorsal skin of recipient mice as described previously (Honaramooz et al. 2002). Briefly, recipient mice were anesthetized with avertin $(0.03 \mathrm{ml} / \mathrm{g})$ and castrated. Their backs were aseptically prepared and four to eight fragments of donor testes were placed under the back skin of each mouse through $\sim 1 \mathrm{~cm}$ incisions. Skin incisions were closed with Michel clips and mice were allowed to recover.

\section{Treatments of recipient mice}

For the acyline experiment, half of the recipient mice of each donor received an s.c. injection of $5 \mathrm{mg} / \mathrm{kg}$ acyline (a kind gift from Dr Richard Blye, NICHD/NIH, Rockville, MD, USA) every 2 weeks (Shetty et al. 2006), while the rest were left as controls. For the PTU experiment, half of recipient mice of each donor were administered $0.1 \%(\mathrm{w} / \mathrm{v})$ PTU (Sigma) added in the drinking water for 4 weeks after surgery. At this time, the PTUcontaining water was withdrawn and mice were fed on normal water. The rest of the mice were left in with normal drinking water to serve as controls. In a preliminary experiment, this PTU treatment resulted in a significant reduction of $\mathrm{T}_{3}$ in treated mice; at 4 weeks the serum concentrations of this hormone were $0.3 \pm 0.2$ and $4.0 \pm 0.3 \mu \mathrm{g} / \mathrm{dl}$ in treated and control mice respectively $(P<0.05)$.

\section{Collection of xenografts and stereological analysis}

Mice were sacrificed by $\mathrm{CO}_{2}$ inhalation at 7 months for the acyline experiment, and 5 and 7 months for the PTU experiment. The weight of their seminal vesicles was recorded as evidence of bioactive testosterone production by xenografts. Xenografts were collected, weighed, fixed overnight in Bouin's solution, and washed in $70 \%$ ethanol. Xenografts were embedded in paraffin or plastic. Sections $(5 \mu \mathrm{m})$ from plasticembedded xenografts were stained with $\mathrm{H} \& \mathrm{E}$ and used for stereological analysis, while those from paraffin-embedded xenografts were used for immunohistochemistry as described below.

In plastic H\&E-stained sections, 30 cord or tubule cross sections were chosen randomly and their diameters were measured at $200 \times$ magnification using an ocular micrometer calibrated with a stage micrometer. In these cross sections, germ cells were identified by their morphology and location, and the most advanced germ cell type present was scored. The volume densities of the donor testis tissue and xenografts components were determined by light microscopy using a 441intersection grid placed in the ocular of the light microscope. In all groups, 15 randomly chosen fields (6615 points) were scored per each section at $400 \times$ magnification. The volume of each component of the testis was determined as the product of the volume density and testis volume and the specific gravity of testis tissue was considered to be 1.0 (França \& Godinho 2003). The total length of seminiferous tubules $(\mathrm{cm})$ was obtained by dividing seminiferous tubule volume by the squared radius of the tubule times $\pi$ (Johnson \& Neaves 1981). For Sertoli cell parameters, the total volume of these cells was achieved during the determination of the volumetric density testicular components. The Sertoli cell nuclear volume was obtained from the knowledge of the mean nuclear diameter and 40 evident nuclei were measured for each xenograft. Nuclear volume was expressed in $\mu \mathrm{m}^{3}$ using the formula: $4 / 3 \pi R^{3}$, where $R$, nuclear diameter/2. The total 
number of Sertoli cells per testis was determined as follows: total number of Sertoli cells per testis $=$ total volume of Sertoli cell nucleus in the testicular parenchyma $(\mu \mathrm{l}) /$ Sertoli cell nuclear volume $\left(\mu \mathrm{m}^{3}\right)$. Regarding Leydig cells, individual Leydig cell volume was obtained from nucleus volume and the proportion between nucleus and cytoplasm. As the Leydig cell nucleus in bovine is spherical, the nucleus volume was calculated from the mean nucleus diameter. For such, 30 nuclei with an evident nucleolus were measured for each donor testis and in the treated and control groups of testis tissue xenograft. Leydig cell nucleus volume was expressed in cubic micrometer and also obtained from the formula $4 / 3 \pi R^{3}$, in which $R$, nuclear diameter/2. To calculate the proportion between nucleus and cytoplasm, a 441-point square lattice was placed over the sectioned material at $400 \times$ magnification and 1000 points over Leydig cells were counted for each testis tissue xenograft. The total number of Leydig cells per testis tissue xenograft was estimated from the individual Leydig cell volume and the volume occupied by Leydig cells in the testis tissue parenchyma.

\section{Immunohistochemical analysis}

Paraffin sections from donor testis and xenografts were stained for UCH-L1, MIS and AR as described previously (RodriguezSosa et al. 2011b). For MIS and AR staining, sections from one adult specimen were used as control (negative for MIS and positive for AR). Briefly, sections were processed through xylene, rehydrated, exposed to $3 \% \mathrm{H}_{2} \mathrm{O}_{2}$ in distilled water for 15 min, washed in PBS for 5 min, and nonspecific binding was blocked in CAS Block (Invitrogen) for $30 \mathrm{~min}$ at room temperature. Tissue sections were subsequently incubated overnight with primary antibodies at $4{ }^{\circ} \mathrm{C}$. Primary antibodies were rabbit anti-UCH-L1 (AbD Serotec, Raleigh, NC, USA), mouse anti-AR, or mouse anti-MIS (both from Santa Cruz Biotechnology, Inc., Santa Cruz, CA, USA), used all at 1:400 dilution in PBS. After washing three times in PBS for 5 min each, the tissue sections were incubated in peroxidaseconjugated goat anti-rabbit or goat anti-mouse $\operatorname{lgG}(2.5 \mu \mathrm{g} / \mathrm{ml})$ for $1 \mathrm{~h}$ at room temperature. After washing in PBS as above, sections were exposed to the chromogen NovaRed (Vector, Burlingame, CA, USA) according to the manufacturer's instructions. For AR and MIS, special care was taken to submit all sections to similar time of exposure to the chromogen. Sections stained for UCH-L1 were then counterstained with hematoxylin for $1 \mathrm{~min}$. All sections were then dehydrated through ethanol, cleared in xylene, and finally mounted in Permount (Fisher Scientific, Ottawa, ON, Canada).

In tissue sections that were stained for $\mathrm{UCH}-\mathrm{L} 1$, cord and tubule cross sections along the longitudinal and transverse axes of each section were scored for the presence of $\mathrm{UCH}-\mathrm{L} 1$ positive cells. Percentage of UCH-L1-positive cross sections and number of UCH-L1-positive cells and Sertoli cells (distinguished by nuclear morphology on the counterstained background) in each section were recorded. For the degree of Sertoli cell maturation, in sections stained for MIS the percentage of cord and tubule cross sections chosen as above and that showed any expression in Sertoli cells was determined. Subsequently, level of MIS expression was evaluated as described previously (Rodriguez-Sosa et al. $2011 b$ ). Briefly, digital images were taken along the longitudinal and transverse axes of sections at defined exposure settings. The seminiferous epithelium in MIS-positive cross sections was outlined and the gray value was determined by densitometry using the AxioVision Software (release 4.8, Carl Zeiss Canada Ltd., Toronto, ON, Canada). Finally, in sections stained for AR the percentage of cord and tubule cross sections that showed any expression in Sertoli cells was also determined.

\section{Statistical analysis}

Seminal vesicles weights, xenograft weights, and stereological parameters were compared by ANOVA and Tukey's test using the GraphPad Prism 5 (GraphPad Software, Inc., La Jolla, CA, USA). Percentages of xenograft recovery were compared by $\chi^{2}$ test using the Frequency (FREQ) procedure of Statistical Analysis Systems Software (SAS, version 9.1.2; SAS, Inc., Cary, NC, USA). Percentages of tubule cross sections with UCH-L1positive cells, and MIS and AR expression, number of UCH-L1positive cells, and transformed gray values of MIS staining were compared by ANOVA and Tukey test using the general linear model procedure of SAS.

\section{Declaration of interest}

The authors declare that there is no conflict of interest that could be perceived as prejudicing the impartiality of the research reported.

\section{Funding}

This study was supported by USDA/CSREES/NRICGP grant (grant number 2007-35203-18213).

\section{Acknowledgements}

We thank Dr Richard $\mathrm{P}$ Blye of the Contraception and Reproductive Health Branch (CHRB) at the NICHD/NIH in Rockville, MD, for kindly providing the acyline used in the current study.

\section{References}

Al-Attar L, Noël K, Dutertre M, Belville C, Forest MG, Burgoyne PS Josso N \& Rey R 1997 Hormonal and cellular regulation of Sertoli cell anti-Müllerian hormone production in the postnatal mouse. Journal of Clinical Investigation 100 1335-1343. (doi:10.1172/JCI119653)

Ariyaratne HB, Ian Mason J \& Mendis-Handagama SM 2000 Effects of thyroid and luteinizing hormones on the onset of precusor cell differentiation in to Leydig cell progenitor cell in the prepubertal rat testis. Biology of Reproduction 63 898-904. (doi:10.1095/biolreprod63. 3.898)

Arregui L, Rathi R, Megee SO, Honaramooz A, Gomendio M, Roldan ERS \& Dobrinski I 2008 Xenografting of sheep testis tissue and isolated cells as a model for preservation of genetic material from endangered ungulates. Reproduction 136 85-93. (doi:10.1530/REP-07-0433)

Baker PJ, Johnston H, Abel M, Charlton HM \& O'Shaughnessy PJ 2003 Differentiation of adult-type Leydig cells occurs in gonadotrophin deficient mice. Reproductive Biology and Endocrinology 14. (doi:10.1186/1477-7827-1-4) 
Banu SK, Aruldhas MM \& Govindarajulu P 2002a Developmental profiles of TSH, sex steroids and their receptors in the thyroid and their relevance to thyroid growth in immature rats. Steroids 67 137-144. (doi:10.1016/ S0039-128X(01)00144-1)

Banu SK, Govindarajulu P \& Aruldhas MM 2002b Sex steroids regulate $\mathrm{TSH}$-induced thyroid growth during sexual maturation in Wistar rats. Experimental and Clinical Endocrinology \& Diabetes 110 37-42. (doi:10.1055/s-2002-19993)

Behringer RR, Cate RL, Froelick GJ, Palmiter RD \& Brinster RL 1990 Abnormal sexual development in transgenic mice chronically expressing Müllerian inhibiting substance. Nature 345 167-170. (doi:10.1038/ 345167a0)

Chandrasekhar Y, D'Occhio MJ, Holland MK \& Setchell BP 1985 Activity of the hypothalamo-pituitary axis and testicular development in prepubertal ram lambs with induced hypothyroidism or hyperthyroidism. Endocrinology 117 1645-1651. (doi:10.1210/endo-117-4-1645)

Chang C, Chen YT, Yeh SD, Xu Q, Wang RS, Guillou F, Lardy H \& Yeh S 2004 Infertility with defective spermatogenesis and hypotestosteronemia in male mice lacking the androgen receptor in Sertoli cells. PNAS 101 6876-6881. (doi:10.1073/pnas.0307306101)

Cooke PS, Zhao YD \& Bunick D 1994 Triiodothyronine inhibits proliferation and stimulates differentiation of cultured neonatal Sertoli cells: possible mechanism for increased adult testis weight and sperm production induced by neonatal goitrogen treatment. Biology of Reproduction $\mathbf{5 1}$ 1000-1005. (doi:10.1095/biolreprod51.5.1000)

Cooke PS, Holsberger DR \& Franca LR 2005 Thyroid hormone regulation of Sertoli cell development. In Sertoli Cell Biology, pp 217-226. Eds MK Skinner\& MD Griswold. London, UK: Elsevier Academic Press.

De Franca LR, Bartke A, Borg KE, Cecim M, Fadden CT, Yagi A \& Russell LD 1994 Sertoli cells in testes containing or lacking germ cells: a comparative study of paracrine effects using the W (c-kit) gene mutant mouse model. Anatomical Record 240 225-232. (doi:10.1002/ar. 1092400209)

De Franca LR, Hess RA, Cooke PS \& Russell LD 1995 Neonatal hypothyroidism causes delayed Sertoli cell maturation in rats treated with propylthiouracil: evidence that the Sertoli cell controls testis growth. Anatomical Record 242 57-69. (doi:10.1002/ar.1092420108)

De Gendt K, Swinnen JV, Saunders PT, Schoonjans L, Dewerchin M, Devos A, Tan K, Atanassova N, Claessens F, Lecureuil C et al. 2004 A Sertoli cell-selective knockout of the androgen receptor causes spermatogenic arrest in meiosis. PNAS 101 1327-1332. (doi:10.1073/ pnas.0308114100)

Dehkordi RAF \& Parchami A 2010 Effect of orchidectomy and chronic androgen administration on thyroid gland in adult male dogs: a light and electron microscopic study. World Applied Sciences Journal 11 289-294.

Ehmcke J, Gassei K, Westernströer B \& Schlatt S 2011 Immature rhesus monkey (Macaca mulatta) testis xenografts show increased growth, but not enhanced seminiferous differentiation, under human chorionic gonadotropin treatment of nude mouse recipients. International Journal of Andrology 34 e459-e467. (doi:10.1111/j.1365-2605.2011. 01179.x)

Fallah-Rad AH, Connor ML \& Del Vecchio RP 2001 Effect of transient early hyperthyroidism on onset of puberty in Suffolk ram lambs. Reproduction 121 639-646. (doi:10.1530/rep.0.1210639)

França LR \& Godinho CL 2003 Testis morphometry, seminiferous epithelium cycle length, and daily sperm production in domestic cats (Felis catus). Biology of Reproduction 68 1554-1561. (doi:10.1095/ biolreprod.102.010652)

van Haaster LH, de Jong FH, Docter R \& de Rooij DG 1993 High neonatal triiodothyronine levels reduce the period of Sertoli cell proliferation and accelerate tubular lumen formation in the rat testis, and increase serum inhibin levels. Endocrinology 133 755-760. (doi:10.1210/en.133.2.755)

Hess RA, Cooke PS, Bunick D \& Kirby JD 1993 Adult testicular enlargement induced by neonatal hypothyroidism is accompanied by increased Sertoli cells. Endocrinology 132 2607-2613. (doi:10.1210/en.132.6. 2607)

Holdcraft RW \& Braun RE 2004 Androgen receptor function is required in Sertoli cells for the terminal differentiation of haploid spermatids. Development 131 459-467. (doi:10.1242/dev.00957)
Honaramooz A, Snedaker A, Bioani M, Schöler H, Dobrinski I \& Schlatt S 2002 Sperm from neonatal testes grafted in mice. Nature 418 778-781. (doi:10.1038/nature00918)

Honaramooz A, Li M, Penedo CT, Meyers S \& Dobrinski I 2004 Accelerated maturation of primate testis by xenografting into mice. Biology of Reproduction 70 1500-1503. (doi:10.1095/biolreprod.103.025536)

Honaramooz A, Cui X, Kim N \& Dobrinski I 2008 Porcine embryos produced after intracytoplasmic sperm injection using xenogeneic pig sperm from neonatal testis tissue grafted in mice. Reproduction, Fertility, and Development 20 802-807. (doi:10.1071/RD08093)

Huang S, Sartini BL \& Parks JE 2008 Spermatogenesis in testis xenografts grafted from pre-pubertal Holstein bulls is re-established by stem cell or early spermatogonia. Animal Reproduction Science 15 1-12. (doi:10.1016/j.anireprosci.2006.11.018)

Jahnukainen K, Ehmcke J \& Schlatt S 2011 Testicular function and fertility preservation in male cancer patients. Best Practice \& Research. Clinical Endocrinology \& Metabolism 25 287-302. (doi:10.1016/j.beem.2010. 09.007)

Johnson L \& Neaves WB 1981 Age-related changes in the Leydig cell population, seminiferous tubules and sperm production in stallions. Biology of Reproduction 24 703-712. (doi:10.1095/biolreprod24.3.703)

Kim Y, Selvaraj V, Pukazhenthi B \& Travis AJ 2007 Effect of donor age on success of spermatogenesis in feline testis xenografts. Reproduction, Fertility, and Development 19 869-876. (doi:10.1071/RD07056)

Kirby JD, Jetton AE, Cooke PS, Hess RA, Bunick D, Ackland JF, Turek FW \& Schwartz NB 1992 Developmental hormonal profiles accompanying the neonatal hypothyroidism-induced increase in adult testicular size and sperm production in the rat. Endocrinology 131 559-565. (doi:10.1210/ en.131.2.559)

Majdic G, Snoj T, Horvat A, Mrkun J, Kosec M \& Cestnik V 1998 Higher thyroid hormone levels in neonatal life result in reduced testis volume in postpubertal bulls. International Journal of Andrology 21 352-357. (doi:10.1046/j.1365-2605.1998.00136.x)

Maran RRM 2003 Thyroid hormones: their role in testicular steroidogenesis. Archives of Andrology 49 375-378. (doi:10.1080/713828213)

McCarrey JR 2003 Development of the germ cell. In Cell and Molecular Biology of the Testis, pp 58-89. Eds C Desjardins\& LL Ewing. New York: Oxford University Press.

McCoard SA, Wise TH \& Ford JJ 2003 Endocrine and molecular influences on testicular development in Meishan and White Composite boars. Journal of Endocrinology 178 405-416. (doi:10.1677/joe.0.1780405)

Miki H, Oshimo K, Inoue H, Morimoto T \& Moden Y 1990 Sex hormone receptors in human thyroid tissue. Cancer 66 1759-1762. (doi:10.1002/ 1097-0142(19901015)66:8<1759::AID-CNCR2820660820>3.0. $\mathrm{CO} ; 2-\mathrm{X})$

Milne KL \& Hayes HM 1981 Epidemiologic features of canine hypothyroidism. Cornell Veterinarian 71 3-14.

Oatley JM, Reeves JJ \& McLean DJ 2005 Establishment of spermatogenesis in neonatal bovine testicular tissue following ectopic xenografting varies with donor age. Biology of Reproduction 72 358-364. (doi:10.1095/ biolreprod.104.030783)

Ojeda SR \& Terasawa E 2002 Neuroendocrine regulation of puberty. In Hormones, Brain and Behavior, pp 589-659, Vol 4. Eds D Pfaff, A Arnold, A Etgen, S Fahrbach, R Moss \& RR Rubin. New York:Elsevier.

Paris MCJ, Snow M, Cox S \& Shaw JM 2004 Xenotransplantation: a tool for reproductive biology and animal conservation? Theriogenology $\mathbf{6 1}$ 277-291. (doi:10.1016/S0093-691X(03)00234-6)

Rathi R, Honaramooz A, Zeng W, Schlatt S \& Dobrinski I 2005 Germ cell fate and seminiferous tubule development in bovine testis xenografts. Reproduction 130 923-929. (doi:10.1530/rep.1.00912)

Rathi R, Honaramooz A, Zeng W, Turner R \& Dobrinski I 2006 Germ cell development in equine testis tissue xenografted into mice. Reproduction 131 1091-1098. (doi:10.1530/rep.1.01101)

Rathi R, Zeng W, Megee S, Conley A, Meyers S \& Dobrinski I 2008 Maturation of testicular tissue from infant monkeys after xenografting into mice. Endocrinology 149 5288-5296. (doi:10.1210/en.2008-0311)

Rawlings NC, Hafs HD \& Swanson LV 1972 Testicular and blood plasma androgens in Holstein bulls from birth through puberty. Journal of Animal Science 34 435-440.

Rodriguez-Sosa JR \& Dobrinski I 2009 Recent developments in testis tissue xenografting. Reproduction 138 187-194. (doi:10.1530/REP-090012) 
Rodriguez-Sosa JR, Foster RA \& Hahnel A 2010 Development of strips of ovine testes after xenografting under the skin of mice and co-transplantation of exogenous spermatogonia with grafts. Reproduction 139 227-235. (doi:10.1530/REP-09-0176)

Rodriguez-Sosa JR, Schlatt S \& Dobrinski I 2011a Testicular tissue transplantation for fertility preservation. In Fertility Preservation: Emerging Technologies and Clinical Applications, pp 331-343. Eds E Seli \& A Agarwal. New York: Springer.

Rodriguez-Sosa JR, Rathi R, Wang Z \& Dobrinski I $2011 b$ Development of bovine fetal tissue after ectopic xenografting in mice. Journal of Andrology 32 271-281. (doi:10.2164/jandrol.110.010322)

Rossi R, Franceschetti P, Maestri E, Cavazzini L, Degli Uberti EC \& Del Senno L 1996 Evidence for androgen receptor gene expression in human thyroid cells and tumors. Journal of Endocrinology 148 77-85. (doi:10. 1677/joe.0.1480077)

Schlatt S, Kim SS \& Gosden R 2002 Spermatogenesis and steroidogenesis in mouse, hamster and monkey testicular tissue after cryopreservation and heterotopic grafting to castrated host. Reproduction 124 339-346. (doi:10.1530/rep.0.1240339)

Schlatt S, Honaramooz A, Bioani M, Schöler RH \& Dobrinski I 2003 Progeny from sperm obtained after ectopic grafting of neonatal mouse testes. Biology of Reproduction 68 2331-2335. (doi:10.1095/biolreprod. 102.014894)

Schlatt S, Gassei K, Westernströer B \& Ehmcke J 2010 Modulating testicular mass in xenografting: a model to explore testis development and endocrine function. Endocrinology 151 4018-4023. (doi:10.1210/en. 2010-0415)

Schmidt JA, de Avila JM \& McLean DJ 2006 Grafting period and donor age affect the potential for spermatogenesis in bovine ectopic testis xenografts. Biology of Reproduction 75 160-166. (doi:10.1095/biolreprod.105.049825)

Senger PL 2003a Regulation of reproduction - nerves, hormones and target tissues. In Pathways to Pregnancy and Parturition, pp 102-127, 2nd revised Edn. Washington: Current Conceptions, Inc.

Senger PL 2003b Endocrinology of the male and spermatogenesis. In Pathways to Pregnancy and Parturition, pp 214-239, 2nd revised Edn. Washington: Current Conceptions, Inc.
Sharpe RM, McKinnell C, Kivlin C \& Fisher JS 2003 Proliferation and functional maturation of Sertoli cells, and their relevance to disorders of testis function in adulthood. Reproduction 125 769-784. (doi:10.1530/ rep.0.1250769)

Sheridan PJ, McGill HC, Jean J, Lissitzky C \& Martin PM 1984 The primate thyroid gland contains receptors for androgens. Endocrinology 115 2690-2693. (doi:10.1210/endo-115-6-2154)

Shetty G, Weng CCY, Porter KL, Zhang Z, Pakarinen P, Kumar TR \& Meistrich ML 2006 Spermatogonial differentiation in juvenile spermatogonial depletion (jsd) mice with androgen receptor or follicle-stimulating hormone mutations. Endocrinology 147 3563-3570. (doi:10.1210/en.20060159)

Snedaker AK, Honaramooz A \& Dobrinski I 2004 A game of cat and mouse: xenografting of testis tissue from domestic kittens results in complete cat spermatogenesis in a mouse host. Journal of Andrology 25 926-930.

Wagner MS, Wajner SM \& Maia AL 2008 The role of thyroid hormone in testicular development and function. Journal of Endocrinology 199 351-365. (doi:10.1677/JOE-08-0218)

Wagner MS, Wajner SM \& Maia AL 2009 Is there a role for thyroid hormone on spermatogenesis? Microscopy Research and Technique 72 796-808. (doi:10.1002/jemt.20759)

Welsh M, Sharpe RM, Moffat L, Atanassova N, Saunders PT, Kilter S, Bergh A \& Smith LB 2010 Androgen action via testicular arteriole smooth muscle cells is important for Leydig cell function, vasomotion and testicular fluid dynamics. PLoS One 5 e13632. (doi:10.1371/journal. pone.0013632)

Zeng W, Avelar GF, Rathi R, Franca LR \& Dobrinski I 2006 The length of the spermatogenic cycle is conserved in porcine and ovine testis xenografts. Journal of Andrology 27 527-533. (doi:10.2164/jandrol.05143)

Received 13 January 2012

First decision 1 March 2012

Revised manuscript received 30 March 2012

Accepted 1 May 2012 